\title{
СТРАТЕГИЧЕСКИЕ ОРИЕНТИРЫ РАЗВИТИЯ ЗЕРНОПРОДУКТОВОГО ПОДКОМПЛЕКСА РОССИЙСКОЙ ФЕДЕРАЦИИ *
}

\author{
(c) 2018 Зюкин Данил Алексеевич \\ кандидат экономических наук \\ Курский государственный университет \\ 305000, г. Курск, улица Радищева, 33 \\ E-mail: nightingale46@rambler.ru
}

В статье рассматриваются вопросы устойчивого развития зернопродуктового подкомплекса АПК. В исследовании изучается Государственная программа РФ «Развитие сельского хозяйства и регулирование рынков сельскохозяйственной продукции, сырья и продовольствия на 2013-2020 годы», в которой представлены индикаторы развития зернопродуктового подкомплекса и величина субсидий, направленных на поддержку ее реализации.

Ключевые слова: зернопродуктовый подкомплекс, зерновое хозяйство, продовольственная безопасность, финансирование, индикаторы стратегического развития зернопродуктового подкомплекса.

Производство зерна является базисом зернопродуктового подкомплекса АПК РФ, определяя вектор развития других направлений аграрного производства. Высокая социальная значимость зернопродуктового подкомплекса в экономике страны обусловлена реализацией направления укрепления обеспечения населения страны продовольствием, что приобрело важное практическое значение в условиях продуктового эмбарго и необходимости решения проблем хлебофуражного снабжения. Экономическая роль зернопродуктового подкомплекса определяется тем, что это наиболее крупный и эффективный сегмент АПК, обладающий высоким экспортным потенциалом, формирует высокую долю в общей величине доходов сельскохозяйственных предприятий.

При этом развитие зернопродуктового подкомплекса выполняет мультипликативное воздействие на конкурентоспособность не только других направлений сельскохозяйственного производства, но и оказывает аналогичное влияние на отрасли не относящихся к АПК. Необходимо учитывать, что усиление интеграционных процессов в форме создания Таможенного союза и Евразийского экономического союза позволяет найти новые направления устойчивого развития бизнес-субъектов зернопродуктового подкомплекса АПК. Также зерно является редким воспроизводимым экспортным товаром, поэтому вступление России в ВТО не оказывает на производство зерна прямого негативного влияния. Поэтому в условиях динамичных социальных, политических и экономических изменений следует пересмотреть стратегические ориентиры развития зернопродуктового подкомплекса, которые были представлены в Государственной программе «Развитие сельского хозяйства и регулирование рынков сельскохозяйственной продукции, сырья и продовольствия на 2013-2020 годы».

Вопросам устойчивого и эффективного развития зернопродуктового подкомплекса уделяется большое внимание в научно-практической литературе. Алтухов А.И. [2] раскрывает суть зернопродуктового подкомплекса страны, определяя ему главную роль в обеспечении производства определенного количества, ассортимента, качества и продуктов переработки зерна, которое бы удовлетворяло потребностям страны в хлебопродуктах, семенах, фуражном зерне и зерне для технической переработки, в создании необходимых запасов и экспортных ресурсов. Поэтому мы считаем, что в условиях возрастающей конкуренции развитие зернопродуктового подкомплекса АПК должно сопровождаться рационализацией затрат и повышении конкурентоспособности конечной продукции в контексте цены и качества [6].

Маремуков А.А. и Хамукова М.А. [7] негативно оценивают ситуацию на зерновом рынке, указывая на низкую значимость роли государства в поддержании рыночного равновесия по отдельным видам зерна, неэффективное распределение доходов между субъектами зернового рынка, неполноценность функционирующей

* Статья подготовлена при финансовой поддержке РФФИ в рамках научного проекта № 18-310-00211 
инфраструктуры, что в совокупности приводит к хаотичности в развитии зернопродуктового подкомплекса АПК.

Гуляева Т.И. и Сидоренко О.В. [5] отмечают, что одним из основных рисков в развитии зернопродуктового подкомплекса является нестабильность объемов производства зерна, являющегося сырьевой основой для пищевой и перерабатывающей промышленности. Авторы утверждают, что агропродовольственная политика Российской Федерации должна быть направлена на устойчивое и стабильное обеспечение перерабатывающей сферы зернопродуктового подкомплекса сырьевыми ресурсами.

Алтухов А.И. и Нечаев В.И. [3] в своих работах неоднократно отмечает несовершенство организационно-экономического механизма зернопродуктового подкомплекса Российской Федерации. Особое внимание автор уделяет инновационному развитию зернопродуктового подкомплекса, основная роль в развитии которого, по его мнению, должна принадлежать государству. Во многих развитых странах оно берет на себя значительную часть затрат, связанных с ускорением научно-технического прогресса, в то время как в России научно-техническая политика должным образом не разрабатывается и не реализуется. Учеными выделен ряд направлений, которые, по их мнению, необходимо усовершенствовать, в целях стратегического развития зернопродуктового подкомплекса. Вот некоторые из них:

- разработка государственной отраслевой целевой программы развития зернового хозяйства и зернового рынка в рамках действующей Государственной программы;

- применение системы гарантированных минимальных цен;

- совершенствование системы закупочных интервенций;

- отработка механизма обеспечения поставок зерна и продуктов его переработки в регионы страны;

- совершенствование режима налогообложения для сельхозтоваропроизводителей;

- формирование стабильной законодательной базы для комплексного развития и зернового хозяйства и рынка зерна и др.

В этой же работе авторы отмечают, что в последние годы значительно ухудшилась эффективность функционирования мукомольно-крупяной и хлебопекарной промышленности, что произошло под влиянием территориально-отраслевого разделения труда, приведшего к ухудшению качественных показателей зерна. А также чрезмерное стремлению к экспорту негативно отражается формирование кормовой базы для животноводства и состояния почв изза систематических нарушений в севооборотах.

Алтухов А.И. [4] подчеркивает необходимость скорейшей разработки стратегии развития зернопродуктового подкомплекса, в которой должны быть представлены схемы размещения и специализации зернового хозяйства в стране. Он считает, что при разработке схем должно быть учтено текущее размещение и специализации сельскохозяйственного производства и предложено создание специализированных высокотехнологичных зон производства отдельных видов зерна, развития инфраструктуры и логистического обеспечения, межрегионального обмена, рационального использования производственного и биоклиматического потенциала.

Итак, крайне необходим анализ и уточнение целевых индикаторов или стратегических ориентиров развития зернопродуктового подкомплекса. Однако для него пока не сформирована отдельная стратегия развития, а только рассматриваются его целевые индикаторы в рамках общей государственной программы «Развитие сельского хозяйства и регулирование рынков сельскохозяйственной продукции, сырья и продовольствия на 2013-2020 годы» (далее Государственная программа) [1].

Среди основных целей по развитию зернопродуктового подкомплекса установлены рост удельного веса сельскохозяйственной продукции российского производства до показателей, предусмотренных Доктриной продовольственной безопасности Российской Федерации (по зерну данный показатель составляет 95\%); доведение валового сбора зерновых и зернобобовых культур до 125 млн. тонн к 2020 г.; производство зернофуража и зернобобовых до 43 млн. тонн; развитие мукомольно-крупяной промышленности, которая предусматривает увеличение объемов глубокой переработки зерна для использования его в смежных отраслях промышленности до 2552 тыс. тонн в год, производство пищевых продуктов на злаковой основе до 500 тыс. тонн в год, производство кормов из отходов крупяной промышленности для животноводства до 705 тыс. тонн в год, производство витаминизированной муки до 3000 тыс. тонн в год. 
Отдельное внимание уделяется элитному семеноводству, основной задачей которого должно стать производство отечественных семян высшей репродукции объемом до 497 тыс. тонн, а удельный вес площади, засеваемой элитными семенами, в общей площади посевов в 2020 г. должен составлять не менее 15\%. Коэффициент обновления тракторного парка к 2020 году должен будет составлять 6,2\%, зерноуборочных и кормоуборочных комбайнов $10 \%$ и 8,6\% соответственно. Более подробно плановые показатели, касающиеся развития зернопродуктового подкомплекса Российской Федерации, приведены в табл. 1.

Главное направление государственной аграрной политики нашей страны - импортозамещение, которое раскрывается в работах многих авторов. Сидоренко О.В. [8], занимаясь исследованием функционирования зернопродуктового подкомплекса в условиях импортозамещения и новой аграрной политики, в качестве стратегических приоритетов его развития обосновала несколько направлений, которые, позволят достичь целевых индикаторов, заложенных в Доктрине продовольственной безопасности Российской Федерации. По ее мнению, для эффективного функционирования зерно- продуктового подкомплекса необходимо производить прогнозирование нормативных валовых сборов зерновых культур, заниматься оптимизацией производственных параметров, повышать эффективность использования продовольственного и фуражного зерна по дивизиональным сегментам с целью удовлетворения потребности населения в продукции его переработки в соответствии с рациональными нормами питания.

Именно устойчивость валовых сборов зерна является ключевым базисом для обеспечения развития направлений пищевой и промышленной переработки и кормопроизводства. В качестве важного индикатора отмечается величина экспорта. На первый взгляд, его увеличение несет только положительное влияние для развития зернового хозяйства, но для комплексного развития зернопродуктового подкомплекса АКП экспорт должен быть всего инструментов, который позволяет санировать зерновой рынок от избытка зерна и обеспечить благоприятную ценовую конъюнктуру для зернопроизводителей. Установленный Государственной программой стратегический ориентир величины экспорта зерна в 20\% от объема производства составляет 24-25 млн. т, однако с 2014 года его фактическая величина превышает 30 млн. т, а в 2017

\section{Таблица 1. Целевые показатели (индикаторы) подпрограмм Государственной программы} и их значения

\begin{tabular}{|c|c|c|c|c|c|}
\hline \multirow{2}{*}{ Индикаторы } & \multicolumn{4}{|c|}{ Годы } & \multirow{2}{*}{$\begin{array}{l}\text { Измене- } \\
\text { ние,\% }\end{array}$} \\
\hline & 2017 & 2018 & 2019 & 2020 & \\
\hline Валовой сбор зерна, млн. т. & 115 & 120 & 123 & 125 & 8,7 \\
\hline - из него: зернофуража, млн. т & 41,1 & 41,9 & 42,8 & 43,6 & 6,1 \\
\hline Доля посевов, засеянных элитными семенами,\% & 15 & 15 & 15 & 15 & - \\
\hline $\begin{array}{l}\text { Глубокая переработка зерна в отраслях промыш- } \\
\text { ленности, тыс. т в год }\end{array}$ & 1484 & 1789 & 2125 & 2552 & 72,0 \\
\hline $\begin{array}{l}\text { Производство пищевых продуктов на злаковой } \\
\text { основе, тыс. т в год }\end{array}$ & 350 & 400 & 450 & 500 & 42,9 \\
\hline $\begin{array}{l}\text { Кормопроизводство из отходов крупяной про- } \\
\text { мышленности для животноводства, тыс. т в год }\end{array}$ & 429 & 521 & 613 & 705 & 64,3 \\
\hline $\begin{array}{l}\text { Объем производства витаминизированной муки, } \\
\text { тыс. т в год }\end{array}$ & 1500 & 2000 & 2500 & 3000 & 100,0 \\
\hline $\begin{array}{l}\text { Доля интервенционного фонда зерна от валовых } \\
\text { сборов,\% }\end{array}$ & 10 & 10 & 10 & 10 & - \\
\hline Доля экспорта зерна от валовых сборов,\% & 20 & 20 & 20 & 20 & - \\
\hline Товарность зерна,\% & 61,5 & 62 & 62,5 & 63 & 1,5 \\
\hline Доля застрахованных посевов зерновых,\% & 27 & 29 & 32 & 34 & 7,0 \\
\hline $\begin{array}{l}\text { Запатентованные сорта сельскохозяйственных } \\
\text { растений в общем количестве, в\% }\end{array}$ & 36 & 40 & 45 & 50 & 14,0 \\
\hline $\begin{array}{l}\text { Количество произведенных семян высшей репро- } \\
\text { дукции, тыс. тонн }\end{array}$ & 428 & 450 & 473 & 497 & 16,1 \\
\hline
\end{tabular}

*Источник. Составлено автором на основе Государственной программы [1] 
году составила 43,3 млн. т. Это показывает, что внутреннее потребление зерна по-прежнему не может обеспечить пропорциональный рост спроса на увеличение урожаев, поэтому высокий экспорт на данном этапе просто необходимый элемент в развитии зернопродуктового подкомплекса. Тем не менее, следует активно развивать внутренний рынок, что также является залогом в эффективной реализации импортозамещения. В этом высока роль государства, влияние которого следует осуществлять как в рамках методов экономического регулирования, так и прямой государственной поддержкой.

Поэтому на реализацию Государственной программы за счет средств федерального бюджета планируется потратить 4,2 трлн. руб. в 2013-2020 гг. В том числе на подпрограммы: «Стимулирование роста производства сельскохозяйственной продукции» планируется затратить 937,8 млрд. руб. с увеличением объема бюджетных ассигнований к концу периода на $30,8 \%$ относительно первого года планового периода; «Поддержка развития пищевых и перерабатывающих отраслей АПК» - 119,4 млрд. руб. с увеличением объема бюджетных ассигнований в 7 раз; «Стимулирование инвестиционной деятельности и инновационного развития АПК» - 860,8 млрд. руб. с увеличением объема бюджетных ассигнований на 58,1\%; «Регулирование рынка сельскохозяйственной продукции, сырья и продовольствия» - 117,1 млрд. руб. с увеличением объема бюджетных ассигнований на 31,2\%; «Развитие инфраструктуры и логистического обеспечения агропродовольственного рынка» - 158,7 млрд. руб. с увеличением объема бюджетных ассигнований в 3,4 раза (табл. 2).

Таким образом, важность прямой финансовой поддержки заключается в подтверждении желания государства участвовать и поддерживать бизнес-элементы зернопродуктового подкомплекса АПК в долгосрочной перспективе. Невыполнение задач, определенных в Государственной программе, повышает вероятность проявления рисков, которые негативно отразятся на развитии зернопродуктового подкомплекса: снижение урожая зерна из-за некачественного семенного материала, неблагоприятных природно-климатических условий, нарушения технологии посевных и уборочных работ, снижения эффективности механизированных работ из-за несвоевременного ввода в эксплуатацию техники, что в дальнейшем приведет к росту цен на зерно на внутреннем рынке и сокращению объемов экспорта.

Поэтому мы считаем, что для развития зернопордуктового подкомплекса необходимо разработать отдельную стратегию, в которой будет показаны перспективы его развития и сформирован более совершенный организационно-экономический механизм функционирования. В конечном результате, важно всеми доступными инструментами не только исключительно рыночного характера, но и прямой финансовой поддержки стимулировать развитие зернопро-

Таблица 2. Целевые показатели (индикаторы) подпрограмм Государственной программы и их значения в 2017-2020 гг.

\begin{tabular}{|c|c|c|c|c|c|}
\hline \multirow{2}{*}{ Направления государственной поддержки } & \multicolumn{4}{|c|}{ Годы } & \multirow{2}{*}{$\begin{array}{c}\text { Измене- } \\
\text { ние, +/- }\end{array}$} \\
\hline & 2017 & 2018 & 2019 & 2020 & \\
\hline $\begin{array}{l}\text { Субсидии по подпрограмме «Стимулирование } \\
\text { роста производства сельскохозяйственной продук- } \\
\text { ции» }\end{array}$ & 118,2 & 119,5 & 119,5 & 120,0 & 1,8 \\
\hline $\begin{array}{l}\text { Субсидии по подпрограмме «Поддержка развития } \\
\text { пищевых и перерабатывающих отраслей АПК» }\end{array}$ & 16,6 & 19,6 & 22,6 & 25,8 & 9,2 \\
\hline $\begin{array}{l}\text { Субсидии по подпрограмме «Стимулирование } \\
\text { инвестиционной деятельности и инновационного } \\
\text { развития АПК» }\end{array}$ & 110,6 & 113,0 & 119,7 & 126,9 & 16,3 \\
\hline $\begin{array}{l}\text { Субсидии по подпрограмме «Регулирование рынка } \\
\text { сельскохозяйственной продукции, сырья и продо- } \\
\text { вольствия» }\end{array}$ & 15,1 & 15,7 & 16,1 & 16,4 & 1,3 \\
\hline $\begin{array}{l}\text { Субсидии по подпрограмме «Развитие инфраструк- } \\
\text { туры и логистического обеспечения агропродо- } \\
\text { вольственного рынка» }\end{array}$ & 21,6 & 25,2 & 28,9 & 32,5 & 10,9 \\
\hline $\begin{array}{l}\text { Субсидии по подпрограмме «Повышение финан- } \\
\text { совой устойчивости сельскохозяйственных товаро- } \\
\text { производителей» }\end{array}$ & 499 & 539 & 582 & 629 & 130,0 \\
\hline
\end{tabular}

"Источник. Составлено автором на основе Государственной программы [1] 
дуктового подкомплекса как основополагающе- ценных продуктов для укрепления продовольго элемента АПК и повысить конкурентоспособ- ственной безопасности населения в хлебофуность производства зерна - одного из наиболее ражном обеспечении.

\section{Библиографический список}

1. Государственная программа «Развитие сельского хозяйства и регулирование рынков сельскохозяйственной продукции, сырья и продовольствия на 2013-2020 годы» (Основные положения). [Электронный ресурс].- Режим доступа: https://refdb.ru/look/2008438-pall.html (Дата обращения: 06.11.2018 г.).

2. Алтухов А.И. Зернопродуктовый подкомплекс АПК страны: проблемы становления и развития // Экономика сельскохозяйственных и перерабатывающих предприятий. 2015. № 6. С. 2-7.

3. Алтухов А.И., Нечаев В.И. Экономические проблемы инновационного развития зернопродуктового подкомплекса России. Москва. 2015. 477 с.

4. Алтухов А.И. Роль территориально-отраслевого разделения труда в агропромышленном производстве страны в обеспечении продовольственной независимости // Региональный вестник. 2015. № 1. С. 2-7.

5. Гуляева Т.И., Сидоренко О.В. Перспективные направления развития зернопродуктового подкомплекса в условиях импортозамещения // Вестник Орловского государственного аграрного университета. 2016. № 3 (60). С. 3-9.

6. Зюкин Д.А. Стратегическое управление природно-экономическим потенциалом зернопродуктового подкомплекса: цели и задачи // Региональный вестник. 2017. № 1. С. 43-45.

7. Маремуков А.А., Хамукова М.А. Формирование системы устойчивого развития зернопродуктового подкомплекса КБР // Экономика и предпринимательство. 2014 . № 7 (78). С. 373-377.

8. Сидоренко О.В. Зернопродуктовый подкомплекс: функционирование и развитие в условиях новой агропромышленной политики. Автореферат диссертации на соискание ученой степени доктора экономических наук / Орловский государственный аграрный университет. Орел, 2015.

Поступила в редакцию 30.10.2018 
